\title{
THE DEAD BRANCH DOCTRINE OF NON-PROFIT ASSOCIATIONS*
}

A comprehensive Non-profit Associations Act must address itself to the issue of changes in the purpose of non-profit associations. There exists a clear divergence in the law as it relates to business corporations and the considerations relevant to non-profit associations in this area. The law regarding a change of purpose of a business corporation requires minimal contemplation, because a business corporation has, in law, only one purpose - profit! Conversely, a non-profit association may be the vehicle for numerous purposes encompassing the entire gamut of human motivations, save one - profit!

The singularity of "profit" as a fundamental purpose of corporations has resulted in the law requiring nothing short of unanimity among all shareholders before the court will sanction a corporate activity motivated by another purpose. This statement of the law is definitively enunciated by Plowman J. in the Parke v. Daily News case. ${ }^{.}$The case concerned an intended plan by the majority of shareholders upon the sale of the company business to give all assets from the sale, over and above the costs arising out of the transaction, to the former employees of the company. There was no contractual obligation on the company to make such a payment, and subsequent to the sale the company would, in effect, no longer be a going concern. It was evident that the company would not derive any benefit from such a distribution of the funds. A small minority of the shareholders objected to the proposed disbursement of sale funds to the former employees. Mr. Justice Plowman, faced with this situation, held: ${ }^{2}$

In my judgment, therefore, the defendants were prompted by motives which, however laudable, and however enlightened from the point of view of industrial relations, were such as the law does not recognize as a sufficient justification. Stripped of all its side issues, the essence of the matter is this, that the directors of the defendant company are proposing that a very large part of its funds should be given to its former employees in order to benefit those employees rather than the com. pany, and that is an application of the company's funds which the law, as I understand it, will not allow.

Mr. Justice Plowman continued on to state that the directors' proposal, although supported by a majority of shareholders, "is one which a majority of shareholders is not entitled to ratify." "The law seems clear that a majority cannot bind a minority to a purpose that forsakes the minority's profit interest in the company; that any alteration of the basic profit motive of a business corporation requires unanimity.

The unanimity requirement in a corporate context is a rational conclusion to the state of affairs that exist. A shareholder attains his interest on the implied understanding that the endeavour will be profit-oriented. It would be a highly inequitable situation that would permit a majority, no

* The research and preliminary draft upon which this note is based were done for the Alberta Institute for Law Research and Reform on the Proposed Alberta Nonprofit Corporations Act project. The author wishes to thank the Institute for permitting him to use this research and, more specifically, Mr. Baz. Edmeades for his perceptive insights and invaluable suggestions. All errors, omissions and defects remain the responsibility of the author.

1. [1962] 3 W.L.R. 566.

2. Id. at 594 .

3. Id. at 594 
matter how large, to unilaterally alter the profit motive of the corporation and dedicate the minority's investment to a different purpose.

The situation is of greater complexity when dealing with non-profit associations. As aforementioned, there exists a plethora of conceivable purposes to which a non-profit association might wish to dedicate itself, ranging from sporting clubs organized for the mutual benefit of their members to worldwide charitable foundations dedicated to the aid of unfortunate third parties. Where there is choice, a change of strategy becomes a greater possibility.

There is, however, not only a difference in number, but also a difference in the nature between the corporate profit strategy and the various nonprofit purposes available. The "corporate profit" motivation has an intangible, amorphous quality which serves to distinguish the profit purpose from the process by which it is earned. In other words, a corporation can make a profit through innumerable methods without altering its fundamental purpose: the end is independent of the means. Whether the means of making the profit is through the manufacturing, distributing, or retailing of endless products in endless ways, the profit strategy of a corporate existence has not been compromised.

In contrast, the purposes of non-profit associations are usually delineated much more narrowly. Rather than having a floating purpose which can attach itself to innumerable different tactics of production, the goals of non-profit associations are inextricably interwoven with the means by which they are achieved. The ends and the means in many instances are inseparable. For example, although many religious organizations are dedicated to the spiritual understanding of the universe, it is what each individual religious group defines as the method by which that understanding is to be achieved that is of integral importance to the members of that particular group. An alteration of the means can lead a member to claim that the overall strategy of the organization has been varied.

A threefold situation results. First, the infinite strategies open to a non-profit association create a situation where a change in the purpose of the association is a greater possibility. Second, due to the narrower definition of purpose that generally accompanies a non-profit association, the need to change basic strategies is much more prevelant. For example, forty years after a war, a non-profit war amputee organization may find it has very little work left to achieve, yet considerable assets. It is quite conceivable that the preferred course of action would be to re-dedicate the assets to another more pressing contemporary cause than either to wind up the association or to let the fund sit idle. Third, because the tactics and the purpose of an association are inseparable, any change in tactics may be viewed as a change in purpose. All of these factors lead to the greater probability of change, or claims by members of change, in the purpose of non-profit associations. The question of what is required by law to change the purpose of an association is therefore of vital importance to any proposed Non-profit Associations Act.

The common law position regarding a change in purpose by a non-profit association has generally been to require unanimity of consent from all members or not to allow change at all. ${ }^{4}$ The theoretical basis for this ap-

4. Craigdallie v. A ikman (1813) 1 Dow. 1,3 E.R. 601: A.-G. ex rel. Mander v.Pearson(1817) 3 Mer. 353, 36 E.R. 135; Free Church of Scotland v. Overtoun [1904] A.C. 515. 
pears to depend on the type of non-profit association with which one is dealing. The courts will follow one of two analyses.

If the association is incorporated, then the courts have traditionally viewed the assets of the association on the basis of an implied trust for whatever purpose the association is dedicated to at the time of the contribution. This is the most common analysis and it is exemplified in Free Church of Scotland v. Overtoun, ${ }^{5}$ where a minority of members objected to a doctrinal change in the Free Church. The minority argued that although the vast majority of members supported the altered doctrine, the funds had been given in trust to the Free Church at a time when the orthodox doctrine was followed, and any change in doctrine would be a breach of trust. The minority further claimed that because the minority continued to adhere to the orthodox tenets of the Church under which the assets had been accumulated, they were the proper trustees of all the assets. The House of Lords held that the distinctive tenets of the Free Church had been altered by the majority and ${ }^{6}$

that the Free Church had no power, where property was concerned, to alter or vary the doctrine of the Church; that ... the United Free Church [the majority group] had not preserved its identity with the Free Church, not having the same distinctive tenets; and that the appellants [the minority] were entitled to hold for behoof of the Free Church the property held by the Free Church....

Lord MacNaughten (dissenting on the grounds that he felt no basic tenets had been breached by the majority) outlined the questions the court will ask in such a situation as follows: ${ }^{7}$

It is alleged on the one hand and denied on the other that there has been a breach of trust in the disposition of property. The complaint is that the funds set apart for one purpose have been diverted to another and different purpose. Such questions are of every day occurrence and the problem in each case must be solved by the ordinary common place inquiry, what was the purpose for which the funds in dispute were collected? What was the original trust?

The trust analysis allows for no change in purpose once property has been given to an association for that purpose.

The alternate analysis which the courts take when the non-profit association is unincorporated is the contract analysis. This analysis accepts the contract theory of unincorporated associations and applies the terms of the contract between the members to the assets of the non-profit organization. The contractual relationship is well described by Rand J. in Orchard v. Tunney, where he states: ${ }^{8}$

Apart, then, from statute, that a union is held together by contractual bonds seems obvious; each member commits himself to a group on a foundation of specific terms governing individual and collective action, a commitment today almost obligatory, and made on both sides with the intent that the rules shall bind them in their relationships to each other. That means that each is bound to all others jointly.

Any modification of an unincorporated non-profit association's purpose will require a novation of contact and, therefore, unanimous approval of all association members. The law in the area is summarized by Blair J.A. in the Polish Veteran's case, as follows: ${ }^{9}$

5. [1904] A.C. 515 .

6. Id. at 516 .

7. Id. at 630 . It should be noted that the courts have allowed themselves some flexibility in the trust analysis. The method by which this is achieved will be discussed below.

8. [1957] S.C.R. 436 at 445.

9. Polish Veterans ' Corps v. Army. Navy and Air Force Veterans in Canada (1978) 87 D.L.R. (3d) 449 at 467 . 
Because of the peculiar nature of the interest of the members of an unincorporated association in the property of the association the courts have been zealous to protect that interest where factions develop and the fellowship of the association is broken. They have been particularly concerned to do this where the fragmented association has split into a disloyal faction, which has gone its separate way and attempted to take the association's property with it, and an ongoing loyal group of adherents seeking to preserve the property and the fellowship of the original association ... It has been held many times that, unless authorized by the organization's constitution, a mere majority of members cannot cause property to be diverted to another association having differing objects.

The purpose to which an unincorporated association is dedicated is either express or implied (by the courts) into the terms of the membership contract. ${ }^{10}$

Apart from unanimity in an unincorporated association, it would appear that a non-profit association's purpose is immutable at common law, unless the terms of the trust or contract specifically provide for a method of change. Although change would seem inevitable in certain associations, no allowance appears to be made for the evolution of non-profit associations "except on pain of forfeiture of its property". "Lord MacNaughton outlined the problem in Free Church of Scotland v. Overtoun when he discussed whether or not the Church could alter its doctrines in any way. He questioned: $:^{12}$

Was the Free Church by the very condition of her existence forced to cling to her subordinate standards with so desperate a grip that she has lost hold and touch with the supreme standard of her faith? Was she from birth incapable of all growth and development? Was she (in a word) a dead branch and not a living Church?

The dead branch analogy focuses on the issue. Should non-profit associations be a dead branch or a living tree?

Undoubtedly there are valid arguments in favor of either a dead branch or a living tree doctrine. The common law trust and contract analyses have merit. The funds are usually given for a purpose and strong objection could be made to any alteration which would change the purpose for which the assets were collected. Too stringent a policy would, however, fail to recognize the inevitable evolution of certain non-profit associations. The courts have recognized this and have allowed for some flexibility.

First, "Subsequent decisions introduced a little play into the system. It became the practice of the courts to differentiate between 'fundamental' departures from past usage and immaterial deviations." 13 It is this method which Lord MacNaughten used in his dissenting opinion in Free Church of Scotland v. Overtoun. Although he recognized the trust analysis, he downplayed the doctrinal changes that occurred, arguing that they were not a fundamental part of the Free Church. As Lord MacNaughten said, "I think this question about the establishment principle is a very small question indeed, and that it occupied a great deal too much of the argument to the exclusion of far weightier matters." 14 Therefore, the trust had not been breached by the alteration in doctrine. Second, to permit flexibility, the courts have implied terms into the contract or trust which would allow alterations. ${ }^{15}$ Such "solutions" however are often an

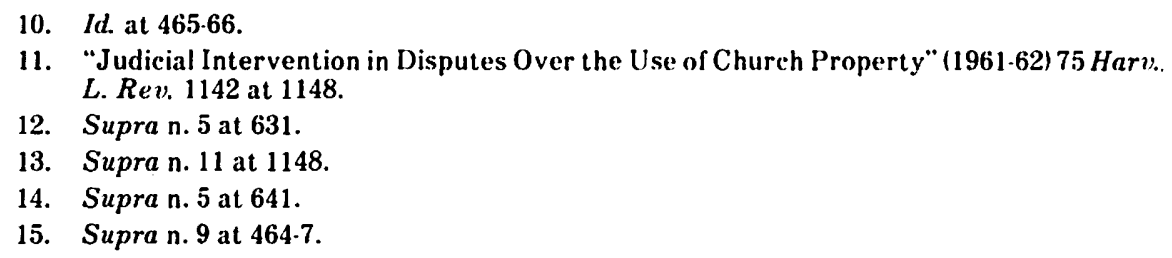


exercise in legal gymnastics. It is suggested that a more straightforward approach would be preferable.

Recently the courts in the United States have done away with the "dead branch doctrine" of trusts as it relates to church assets, in two case $^{16}$ on the constitutional basis that: ${ }^{17}$

First Amendment values are plainly jeopardized when church property litigation is made to turn on the resolution by civil courts of controversies over religious doctrine and practice. If civil courts undertake to resolve such controversies in order to adjudicate the property dispute, the hazards are ever present of inhibiting the free development of religious doctrine and of implicating secular interests in matters of purely ecclesiastical concern.

In its place, the Supreme Court of the United States has applied, what it has coined the 'neutral-principles' approach, which was outlined by the court in Jones v. Wolf as follows: ${ }^{18}$

The neutral-principles method ... requires a civil court to examine certain religious docu. ments, such as a church constitution, for language of trust in favor of the general church. In undertaking such an examination, a civil court must take special care to scrutinize the document in purely secular terms, and not to rely on religious precepts in determining whether the document indicates that the parties have intended to create a trust. In addition, there may be cases where the deed, corporate charter, or the constitution of the general church incorporates religious concepts in the provisions relating to the ownership of propert $y$. If in such a case the interpretation of the instruments of ownership would require the civil court to resolve a religious controversy, then the court must defer to the resolution of the doctrinal issues by the authoritative ecclesiastical body.

On balance, however, the promise of nonentanglement and neutrality inherent in the neutralprinciples approach more than compensates for what will be occasional problems in application.

The approach is not without difficulty. ${ }^{19}$ Although the consensus is towards a secularized analysis of property ownership from a trust perspective, it would appear that there is no real agreement on the legal theory behind the decisions. ${ }^{20}$ The law in the United States will allow a change in church doctrine, but it is not clear in what situations the change will be allowed.

In consideration of the law as it presently exists, the following proposition is put forth, hopefully, as a solution. It is felt that any comprehensive Non-profit Associations Act must accommodate the need that certain non-profit associations have to evolve. A strict dead branch policy is too restrictive and would only force the courts surreptitiously to allow changes in purpose, as they are presently doing. It is felt that a better answer is to recognize by statute that the trust to which funds are given can be altered. Lord MacNaughten in dissent in the Overtoun case asserted that the implied trust of the church in that case allowed change, by stating as follows: ${ }^{21}$

16. Presbyterian Church v. Mary E.B. Hull Memorial Presbyterian Church 393 U.S. 440 and Jones v. Wolf 443 U.S. 595.

17. 393 U.S. 440 at 449.

18. 443 U.S. 595 at 604.

19. The Supreme Court has adopted circular reasoning on this point. If doctrine is a question, it must be resolved by the "authoritative ecclesiastical body". But the very issue being litigated is "Who represents that body?". Whoever is found to be the authoritative body will inevitably rule that their own doctrinal interpretation is the correct one. In ef. fect, the Supreme Court still has to decide to whom the property will go, but by using this technique, the Supreme Court has allowed itself to simply give the property to the majority group. The majority opinion is their determinant of the "authoritative ecclesiastical body".

20. Dallin H. Oaks, "Trust Doctrines in Church Controversies" 1981 B.Y.U.L. Rev. 805 at 901-904.

21. Supra n. 5 at $635 \cdot 6$. 
Then for whom and for what purpose was the money collected? Except as regards sums devoted to special purposes and special objects, the fund was all one fund. It was collected for the needs of the Free Church of Scotland. And what was the Free Church? Did it go out as a Sect or as a Persuasion or a Connection, with peculiar tenets cut and dried and defined in the precise language of a conveyancer? Nothing of the kind ....

Speaking for myself, I cannot form a conception of a National Church untrammelled and unfettered by connection with the State which does not at least possess the power of revising and amending the formulae of subscription ... and the power of pronouncing authoritatively that some latitude of opinion is permissible....

This writer agrees with Lord MacNaughten's view, as well as his reasoning, that it is a term of the very trust that some latitude must be given certain non-profit associations. It is recognized, however, that there may also be associations where it is expedient or desirable to have a well defined unalterable trust on all property. This should also be accommodated.

The proposed solution is to allow statutorily a non-profit association to change its purpose with a majority, unless the association specifically provides otherwise. The majority could be two-thirds, three-quarters, or whatever is deemed appropriate. This solution would adopt the common law trust and contract analyses. However, it would make it an express term of the trust or contract that change is possible with the assent of the statutorily prescribed majority or with whatever conditions the nonprofit association would impose on itself. The major difference that results is that a non-profit association would then be able to alter its purpose unless it had expressly provided otherwise, whereas at common law the inverse was true; the association could not change its purpose unless it expressly provided otherwise. This solution has the advantage of flexibility, in that an association can still set the conditions of its own trust, and the presumption of change is now overt. Also, by stating statutorily the ability of a non-profit association to change its purpose, it is hoped that associations will be forced to consider the issue where they have often failed to do so in the past. It is felt this solution adopts the wisdom of the common law yet recognizes the possible evolution of purpose of non-profit associations.

Victor Lirette

LL.B. Candidate

University of Alberta 